\title{
Protection of Personal Non-Property Rights in the Field of Information Communications: A Comparative Approach
}

\author{
Viktoriia Formaniuk $^{1}$, Oksana Kanienberh-Sandul ${ }^{1}$, Oksana Palii ${ }^{2}$, Anastasiia Borysova $^{3}$ \& Anna Manuilova ${ }^{1}$ \\ ${ }^{1}$ Department of International and European Law, National University “Odesa Law Academy”, Odesa, Ukraine \\ ${ }^{2}$ Department of Philosophy, National University “Odesa Law Academy”, Odesa, Ukraine \\ ${ }^{3}$ Department of Civil and Commercial Law and Process, International Humanities University, Odesa, Ukraine \\ Correspondence: Viktoriia Formaniuk, National University “Odesa Law Academy”, Odesa, Ukraine. E-mail: \\ v774910@gmail.com
}

Received: June 25, 2020

Accepted: July 29, 2020

Online Published: August 30, 2020

doi:10.5539/jpl.v13n3p226

URL: https://doi.org/10.5539/jpl.v13n3p226

\begin{abstract}
The issues which arise in connection with the use of information technologies are analysed in the paper. The attention is focused on the protection of non-property rights, such as honour, dignity, business reputation, violated on the Internet. It is noted that today there is a significant increase in the volume of legal regulation in this area. Nevertheless, there are still significant gaps in the protection of human rights, violated on the Internet. The current level of development of these processes objectively requires the creation of effective mechanisms and means to protect human rights and freedoms, including personal non-property rights. The existing ways of protection of persons on the Internet, such as judicial protection and self-defense are compared in the paper, there advantages and drawbacks are revealed. The types of violations of non-property rights of persons on the Internet are investigated. The specific attention is paid to cyberbullying. Some issues typical for communication on the Internet, such as difficulties in identifying where exactly the offence was committed and which court the claim should be addressed as well as the identification of the offender are revealed. Some shortcomings in the legal regulation of protection of persons on the Internet and ways to eliminate them are analyzed.
\end{abstract}

Keywords: information technologies, non-property rights, Internet, honour, dignity, business reputation, compensation

\section{Introduction}

One of the important components of modern development of all countries is the further establishment of human rights and freedoms, and the active formation of the information society, the development of information technology, the creation of a highly effective information environment. These processes are the result of the direct impact of globalization and informatization, the constant development of information, communication and other technologies, which are becoming increasingly important.

Full protection of individuals on the Internet requires not only the available IT tools to ensure it, but also proper legislation on the protection of individuals on the Internet, which would correspond to modern types of violations of human rights on the Internet and ways to protect individuals from such violations. The rights of individuals, including access to information and other rights exercised through the Internet, are not possible without adequate protection of individuals directly on the Internet against possible violations of such rights. Therefore, modern methods of protection of persons on the Internet should be used at the very first stage of the violation of the rights of persons and immediately after receiving information about such violations. Given the characteristics of the Internet, modern preventive means of protection of persons should be provided, which combine reliable technological possibilities for their implementation and legislative consolidation of the possibility to use them. The application of only a judicial method of protection of persons whose rights have been violated on the Internet is ineffective due to the speed of its application compared to the rate of repeated violations of the rights of persons on the Internet.

Given the multifaceted nature of the Internet and, consequently, the relationships that arise from its use, it is worth noting the obvious diversity of views of scientists, experts on determining the legal nature of the Internet, the relationships that arise there. There are significant differences in the views of scholars on the need and features of 
legal regulation of such relations, in approaches to determining the composition of subjects, objects of Internet legal relations, means of protection of persons on the Internet and types of violations of human rights committed on the Internet. This necessitates research aimed at determining the features of the legal regulation of relations on the Internet. In particular, the problems of protection of personal non-property rights as fundamental human rights become especially important.

\section{Material Studied, Area Descriptions, Methods}

The problems of civil law regulation and protection of personal non-property rights of an individual have previously received some attention by scholars both in Ukraine and abroad. One of the first Ukrainian works on this issue was the dissertation of $Z$. Romovska which was focused on the study of personal non-property rights of an individual in Ukraine. Later some more dissertations on this topic were completed in Ukraine (L. Krasytska "Problems of realization and protection of personal non-property and property rights of parents and children"1, L. Korchevna "Compensation for non-pecuniary damage caused by violation of personal non-property rights in the civil law of Ukraine"2). In other countries, these rights were studied by M. Maleina ("Personal non-property rights of citizens: the concept, implementation and protection"3), D. Zaharov ("Theoretical and practical problems of protection of personal non-property rights of citizens" ${ }^{\prime 4}$. Some key aspects of the protection of non-property rights we can find in European legal literature (H. Bosher ${ }^{5}$, E. Perrot \& F. Mostert ${ }^{6}$, P. Vinck ${ }^{7}$, J. Denley \& A. Barak ${ }^{8}$, C. O’Regan ${ }^{9}$.

The works of these jurists have made a significant contribution to the development of civil law regulation, implementation and protection of personal non-property rights of individuals and a solid scientific foundation for further research in this area, an important step towards improving legislation and ensuring full implementation of personal rights. Nevertheless, the issue of the protection of non-property rights in the field of information communications remains uncovered.

Therefore, the purpose of this work is to characterize the existing ways of protection of persons on the Internet, to investigate the types of violations of non-property rights of persons on the Internet, as well as to identify shortcomings in the legal regulation of protection of persons on the Internet.

General and special scientific methods were used in the process of research. As material for study were used social relations arose in the sphere of legal protection of non-property rights in the field of information technologies. Methodological basis for study was a dialectical method that allowed to review the issues in their development and interconnection.

Using the formal-logical method, the provisions of the legal acts in the field of non-property rights protection have been analyzed.

The formal-logical method gave the opportunity to study the provisions of the legal acts of Ukraine and the European Union on the protection of non-property rights.

The current situation and needs in the field of non-property rights protection on the Internet were revealed using dogmatic and legal methods.

\section{Results and Discussion}

\subsection{Some Issues of the Protection of Non-Property Rights on the Internet}

The development of information technology in recent years has not only expanded opportunities for

\footnotetext{
${ }^{1}$ Krasytska L. (2015). Problems of realization and protection of personal non-property and property rights of parents and children. Abstract of PhD Thesis. Kyiv: National Academy of the Prosecutor's Office of Ukraine, 49 p.

${ }^{2}$ Korchevna L. (1998). Compensation for non-pecuniary damage caused by violation of personal non-property rights in the civil law of Ukraine. Abstract of PhD Thesis. Kharkiv: University of Internal Affairs, $24 \mathrm{p}$.

${ }^{3}$ Maleina M. (2000). Personal non-property rights of citizens: the concept, implementation and protection. Moscow: MZ Press, 244 p.

${ }^{4}$ Zaharov D. (2007). Theoretical and practical problems of protection of personal non-property rights of citizens. Abstract of $\mathrm{PhD}$ Thesis. Moscow: Russian Academy of Civil Service under the President of the Russian Federation, $34 \mathrm{p}$.

${ }^{5}$ Bosher H. (2020). Key issues around copyright and social media: ownership, infringement and liability. Journal of intellectual law and practice, 14(2), p. 123-133.

${ }^{6}$ Perot E. \& Mostert F. (2020). Fake it till you make it: an examination of the US and English approaches to persona protection as applied to deepfakes on social media. Journal of intellectual law and practice, 15(1), p. 32-39.

${ }^{7}$ Vinck P. (2019). Transitional Justice in the Age of Social Media. International journal of transitional justice, 13(1), p. 105-112.

${ }^{8}$ Denley J. \& Ariel B. (2019). Whom Should We Target to Prevent? Analysis of Organized Crime in England using Intelligence Records. European journal of crime criminal law and criminal justice, 27(1), p. 13-44.

${ }^{9}$ O’Regan C. (2018). Hate Speech Online: an (Intractable) Contemporary Challenge? Current legal problems, 71(1), p. 403-429.
} 
communication, exchange of information without borders, time and age, but also provided society with more opportunities to exercise their right to freedom of speech, thought and free expression of their beliefs. The ideal platform for the realization of these and other rights has become the Internet and particularly, social networks, various applications. However, it is the evolution of opportunities for communication, expression of one's own opinion, beliefs and views, which at the same time contributed to the abuse of such rights and led to violation of other people's rights through expression, dissemination of inaccurate information about individuals or legal entities.

At the legislative level, a number of normative legal acts are devoted to the issue of violation of personal nonproperty rights of individuals and legal entities, however, they also insufficiently regulate problematic situations that may arise during protection of honor, dignity and business reputation of a legal entity on the Internet ${ }^{10}$.

Article 3 of the Constitution of Ukraine defines a person, his life, honor and dignity, inviolability and security as the highest social value, and Article 28 of the Constitution of Ukraine guarantees the right of everyone to respect for his dignity and declares that no one shall be subjected to torture or cruel, inhuman or degrading treatment or punishment. The right to respect for dignity and honor, among others, in Article 270 of the Civil Code of Ukraine ${ }^{11}$, refers to personal non-property rights. The lack of definition of the concepts of "honor", "dignity" and respect for honor and dignity among the legal acts is understandable, because these categories are primarily moral and ethical rather than legal. Although violations of moral and ethical norms have legal consequences, which can be traced precisely to ensuring these rights not only at the legislative level, but also through attempts to settle in practice while protecting the honor and dignity of individuals and business reputation of individuals and legal entities.

The Resolution of the Plenum of the Supreme Court of Ukraine of 27.02.2009 "On judicial practice in cases of protection of dignity and honor of individuals, as well as the business reputation of individuals and legal entities"12 (hereinafter - Resolution) defines the concepts of "dignity", "honor", "business reputation of individuals", "business reputation of a legal entity". However, the greatest difficulty in protecting the honor, dignity or business reputation of an individual is the distinction between the concept of "unreliable information" from a similar concept of "negative information". The above-mentioned Resolution states that inaccurate information is untrue or false (contains information about events or phenomena that did not exist or existed, but information about which is incomplete or distorted), but a clear definition of "inaccurate information" or "false information" does not exist in the law. Instead, part 3 of Article 277 of the Civil Code of Ukraine enshrines the presumption of unreliability of negative information, i.e. negative information is considered unreliable until the person who disseminated it proves otherwise. According to the definition of "negative information" it is necessary to refer to the Resolution, according to which negative information is considered as such if it alleges violation by a person, in particular, current legislation, any other actions (violation of the principles of morality, generally accepted rules of coexistence, unethical behavior in personal, social or political life, etc.) and which, in the opinion of the plaintiff, violates his or her right to respect for dignity, honor or business reputation.

In order to properly protect one's violated right to respect for honor, dignity, and business reputation, it is necessary to distinguish the dissemination of false information from evaluative judgments and to take into account the redundancy of language, as the same sentence can be interpreted by different people. It is possible that in this case the principle developed in the case law of the European Court of Human Rights will be effective. According to the Court's position, the facts can be proved and the existence of evaluative judgments - no, so the plaintiff must determine this in advance and also request a linguistic study ${ }^{13}$.

One of the negative features of social media is the anonymity of users, which in turn contributes to the disappearance of a sense of reality, so some things that a person does not dare to express in "real" life, expresses them in "virtual", relying on impunity. Accordingly, users do not feel the difference between expressing their opinion in the proper form and in the brutal. On the Internet, such people are called haters, i.e. people who under a nickname (hiding their own name) in a very negative way criticize a certain person. There is another group of critics - trolls who brutally criticize (sometimes go beyond discrimination) all users of the Web, not specifically

\footnotetext{
${ }^{10}$ Hetman A. \& Efremova K. (2016). Legal nature of Internet legal relations. Legal regulation of relations on the Internet. Kharkiv: "Law", p. $8-22$.

${ }^{11}$ Verkhovna Rada of Ukraine. (2003). Civil Code of Ukraine adopted on January 16, 2006. Vidomosti of the Verkhovna Rada of Ukraine. 2003. №3. Art. 356 .

12 The Supreme Court of Ukraine. (2009). On judicial practice in cases of protection of dignity and honor of individuals, as well as the business reputation of individuals and legal entities: The Resolution of the Plenum of the Supreme Court of Ukraine of February 27, 2009. Visnyk of the Supreme Court of Ukraine. 2009. №3. P. 7.

13 Bezzub I. (2018). Fight against Internet piracy in Ukraine: expert assessment. [online]. Retrieved from: http://nbuviap.gov.ua/index.php?option=com_content\&view=article\&id=874:internet-piratstvo\&catid=8\&Itemid=350 [Accessed 10 June, 2020].
} 
selecting the victim, not looking for information about her, as haters $\mathrm{do}^{14}$.

The negative point of creating your own profile on a social network is the high probability that a person may come under pressure from either haters or trolls. Of course, in addition to the moral and ethical side of this issue there is a legal one, because the difficulty in protecting a person from hatred, trolling is that even going to court to protect honor, dignity, it is difficult to find a person who encroached on them. That is, there are many questions: who was the author of an offensive comment, publication, whether he was on the Web under his own name and wrote a comment, or it was another person who in any way logged in to the Web under the name of another person and wrote this comment. There is also a risk that after learning about the offended person's appeal to the court, the offender may delete all comments, publications that would prove his guilt, i.e. there is a risk of disappearance of evidence, and their recovery, obtaining from the administration of social networks or other applications takes time or turns out to be impossible.

According to O. Radkevych, one of the main ways of violating personal non-property human rights on the Internet is that an attacker pretends to be a user and manipulates user's data. In this case, there is an interference in the relationship between the two interlocutors, in which the mediator changes, deletes the information transmitted by the interlocutors. Computer viruses (special programs) not only damage, redirect, delete personal data, but also transfer them to another computer device for further distribution. There are also special programs that are used to select passwords to access confidential information that is not only on computer devices, but also on the user's network ${ }^{15}$.

Part one of Article 277 of the Civil Code of Ukraine provides for the right to reply, as well as to refute inaccurate information about an individual or members of his family, as a result of the dissemination of which there was a violation of personal non-property rights of such person. In this case, the right of reply belongs to the person in respect of whom inaccurate information was disseminated, and exercising this right, it highlights its own point of view on the disseminated information and the circumstances of violation of personal non-property rights without declaring it unreliable ${ }^{16}$. Rebuttal of inaccurate information is carried out by the person who disseminated it.

The decision of the Plenum of the Supreme Court of Ukraine of February 27, 2009 states that the dissemination of information is its publication in the press, broadcast on radio, television or using other media; distribution on the Internet or using other means of telecommunications; summons in characteristics, statements, letters addressed to other persons; messages in public speeches, in electronic networks, as well as in another form to at least one person.

The benefit of the Internet, in addition to the ability to search for information, for modern people is also that they can create their own information, share it or information from others, from other sources, sometimes not even necessarily known to the person. Since social networks are a popular place for communication, search and dissemination of information, it should be said that they provide convenient ways to disseminate information create it on your own page (accounts, personal profile) and transfer information to your page from other sources, so called "repost", "retweet", etc. If in real life the question of dissemination of information seems clear, because there are ways, actions, means by which information is disseminated, the ways of its dissemination on the Internet raise a number of questions, including: should a person who makes "repost", "retweet" be considered as an author of such information.

The Terms of Use of most social networks state that the user (owner of the profile, personal page) is responsible for any actions, posted texts, etc., the owner of the personal page owns the materials published by him. ${ }^{17}$ That is, by publishing information on his page under his nickname, the user is personally responsible for it, and the materials posted by him are considered his own (of course, except for the reservations provided by the Terms of Use of intellectual property rights). So knowing the nickname, the person, who applies to the court for protection of honor, dignity, business reputation knows the person who disseminates information that violates this right. However, in practice there is a difficulty in proving that the owner of the nickname, profile, personal page, website disseminated this information, thereby violating the right to respect for the honor, dignity of the individual and the

\footnotetext{
14 Tsesis A. (2017). Terrorist Speech on Social Media. Vanderbilt Law review, 70 (2), p. 651-708.

${ }^{15}$ Radkevitch O. (2011). Features of violation of non-property rights of the person on the Internet. Legal, normative and metrological support of the information protection system in Ukraine, 1(22), p. 25-29.

${ }^{16}$ Nyamutata C. (2019). Childhood in the digital age: a socio-cultural and legal analysis of the UK's proposed virtual legal duty of care. International journal of law and information technology, 27 (4), p. 311-388. Doi 10.1093/ijlit/eaz010

${ }^{17}$ Instagram. (2020). Community Guidelines. [online] Retrieved from: https://help.instagram.com/477434105621119?helpref=page_content [Accessed 10 June, 2020].
} 
business reputation of individuals and legal entities ${ }^{18}$.

Legal regulation of the protection of honor, dignity of a natural person and business reputation of a legal entity at the legislative level and its effectiveness in terms of practical implementation indicates the relative sufficiency of ways to protect a person from widespread inaccurate information in "real life", i.e. when such information is disseminated using traditional sources of knowledge, namely through the media: print media, radio, television. However, a feature of the Internet is the high speed of dissemination and the associated risk of misrepresentation compared to pre-existing media. For this reason, the ways to protect the honor, dignity of an individual, the business reputation of a legal entity, which are provided by current legislation, along with their positive features, have negative aspects associated with low efficiency in the "virtual world".

Inaccurate information that violates the rights of individuals and legal entities is quickly spread on the Internet not only through so-called reposts, likes, comments and likes in other ways, but also due to the very nature of the Internet and its main characteristic - speed. Therefore, awareness of unreliable information of a wide range of people, compared to, for example, the distribution of a newspaper or magazine, will be faster, and the owner of the website, application, social network and other communication channels on the Internet to refute such unreliable information, does not always guarantee adequate compensation to the victim for disseminating inaccurate information about him ${ }^{19}$. It happens since the very mention of the existence of inaccurate information in the rebuttal will arouse even greater interest in it than the fact of rebuttal, and posting a text refuting inaccurate information does not guarantee that "shared" on their page ("reposted", "retweeted") will also spread the refutation. Thus, among other things, the legislation should provide a more effective way to protect the honor, dignity of the individual, the business reputation of individuals and legal entities from the dissemination of inaccurate information on the Internet.

The protection of the honor, dignity and business reputation of public figures is somewhat different. According to Resolution 1165 (1998) of the Parliamentary Assembly of the Council of Europe "On the right to privacy"20, there are persons holding public office and (or) using public resources, as well as all those who play a certain role in public life (in politics, economics, art, social sphere, sports or in any other field). A politician has the right to protection of his private life, but the limit of protection of his reputation must be such as to ensure free discussion of political issues. Politicians inevitably become open to meticulous coverage of their words and actions and must be aware of this. At the same time, the press should not cross the line set to protect the reputation of others, but should report information and ideas on political issues, as well as on issues of public interest. Not only the press has the task of reporting such information, but also the public has the right to receive it. ${ }^{21}$ That is, the limit of permissible criticism of a politician or other public figure is much wider than that of an ordinary person.

It is also worth noting that in the European legal system, for example, there is such an element of the right to the protection of personal data as the right to be forgotten, which provides for the possibility for a person to request the destruction of his or her data in certain circumstances. Although the "right to be forgotten" is somewhat similar to the right to privacy, there is a difference between them ${ }^{22}$. In the case of the "right to be forgotten", the selfrealization of a person in public space is manifested in the creation of one's own history, which is very similar to the "right to identity", the ability to form one's own image, to develop it in communication with other people. This right is enshrined in Directive 95/46 / EC ${ }^{23}$ as well as in the Law of Ukraine "On Personal Data Protection"24. An example of this right is the ruling of the European Court of Human Rights in the case of Costeja González v. Google, according to which Google must remove inadequate, "untrue or irrelevant" data from its results when

\footnotetext{
${ }^{18}$ Pelekh M. \& Shopinski T. (2014). Consumer protection in the field of e-commerce. Bulletin of the Ministry of Justice of Ukraine, 9, p. 123128.

19 Galyantych M. (2011). Compensation for moral and material damage. Kyiv: Jurinkom Inter, 624 p.

${ }^{20}$ Parliamentary Assembly of the Council of Europe. (1998). On the right to privacy: Resolution 1165 (1998) of the Parliamentary Assembly of the Council of Europe. [online]. Retrieved from: https://assembly.coe.int/nw/xml/XRef/Xref-XML2HTMLen.asp?fileid $=16641 \&$ lang $\% 20=$ en

${ }^{21}$ Kulinich O. (2012). Certain issues of case law on the legality of the distribution of photographic works depicting "public" individuals. Current issues of state and law, 68, p. 359-365.

${ }^{22}$ Fernandez J.P. (2017). Data protection and Internet search engines: current issues and future perspectives about the right to be forgotten. Revista de derecho civil, 4 (4), p. 181-209.

${ }^{23}$ European Parliament and the Council of Europe. (1995). Directive 95/46/EC of the European Parliament and of the Council of 24 October 1995 on the protection of individuals with regard to the processing of personal data and on the free movement of such data. [online]. Retrieved from: https://eur-lex.europa.eu/legal-content/en/TXT/?uri=CELEX\%3A31995L0046. [Accessed 10 June, 2020].

${ }^{24}$ Verkhovna Rada of Ukraine. (2010). On Personal Data Protection: Law of Ukraine of June 1, 2003 No. 2297-VI. Vidomosti of the Verkhovna Rada of Ukraine. 2010. №34. Art. 481.
} 
someone in society asks it to do so. ${ }^{25}$

All the above ways to protect the honor, dignity of the individual and the business reputation of individuals and legal entities involve recourse to the courts. However, in our opinion, before going to court, it worth trying all the proposed by law and on the Internet methods of self-defense and pre-trial settlement of the dispute, by personally contacting (or through a lawyer) the author of inaccurate information to remove it or not distribute it, to hosting provider, website administrator with a complaint against such an author. As a rule, such users are blocked or the publication is deleted. In any case the victim of violation of his right to respect for the honor of dignity has the right to judicial protection.

\subsection{Peculiarities of Protection of Non-Property Rights in Social Media}

As the Internet is designed not only to search and post information, but also to communicate, the popularity of social networks, which best meet the human need for communication, grows rapidly.

However, despite the convenience and speed of Internet communication, social networks, as the most typical platforms for this, are associated with a high risk of human rights violations, as well as the difficulties of judicial protection of such rights ${ }^{26}$. Problems of protection of persons in social networks can be divided into those related to insufficient legal regulation of the status of social networks and the lack of technical capabilities or inability to protect persons in social networks ${ }^{27}$.

The most common problems that do not have legal regulation are as follows. First, it is the lack of unified principles of legal regulation of relations in social networks. Secondly, there are no clearly established principles of protection and liability for infringement of intellectual property rights on social networks. Third, the problems of legal regulation of advertising, e-commerce and the use of trademarks on social networks have not been resolved. Finally, the issues of information security and protection of personal data of social network users remain problematic ${ }^{28}$.

It should be noted that the activities of Cyberpolice play an important role in the protection of individuals on social networks in Ukraine. For example, officers of the Kyiv Department of the Cyberpolice Department of the National Police of Ukraine together with the Investigative Department of the Kyiv Region Police exposed a 40-year-old resident of Kyiv Region who sold personal data of Ukrainians on the Internet for money. ${ }^{29}$ Such kind of infringements are quite typical for Ukraine. It is the personal data of social network users that become the most vulnerable. In this regard, analyzing one of the most popular social networks Facebook, it is worth noting some rules using which the user of the social network, can prevent the violation of his or her rights.

According to M. Moskalenko, to use a social network securely, you should first create a strong password; do not indicate the full date of your birth, limited to the day and month, and at best - do not specify anything, especially phone number and place of residence; restrict access to your biography, allow it to be viewed only by friends. ${ }^{30}$ Researchers note that in order to find reliable means of protection in social networks, it is necessary to know the means of violating the rights of persons in social networks, including:

1) capturing mail to intercept the password from the page on the social network;

2) fake letters allegedly from technical support, because by responding to them, the user discloses his or her personal data;

3) phishing, which is used to create a similar to the original site of the social network, but with a different address in the appropriate field, so the user, not paying attention to it and filling in all the data of his page passes them to fraudsters;

4) using cookies that the site transmits to the user's computer at login, which are stored on the user's computer, because if the hacker receives a cookie, he will be able to read personal correspondence and send messages on

${ }^{25}$ Suhorolskiy P. (2016). The right to be forgotten in the legal system of the European Union: realities, problems and prospects. The science of international law at the turn of the century. Tendencies of development and transformation: special edition of scientific articles. Lviv: Ivan Franko Lviv National University, p. 90-101.

${ }^{26}$ United Nations General Assembly. (2016). The promotion, protection and enjoyment of human rights on the Internet. [online]. Retrieved from: https://www.article19.org/data/files/Internet_Statement_Adopted.pdf_[Accessed 15 June, 2020].

${ }^{27}$ Cubero D. (2017). The freedom of information facing the Internet. Revista de derecho politico, 100, p. 701-737.

${ }^{28}$ Baadzhi N. (2017). Legal nature of legal relations on the Internet. Journal of Civil law, 22, p. 112-116.

${ }_{29}$ Cyberpolice Department of the National Police of Ukraine. (2017). Cyberpolice found an ex-official who "traded" personal data of Ukrainians. [online]. Retrieved from: https://cyberpolice.gov.ua/news/kiberpolicziya-vykryla-eks-posadovczya-yakyj-torguvavpersonalnymy-danymy-ukrayincziv-foto-video-3672/ [Accessed 15 June, 2020].

${ }^{30}$ Moskalenko M. (2016). Information protection in social networks. Current issues and achievements in the field of cybersecurity, 3, p. 143144. 
behalf of the user. ${ }^{31}$

In addition to the misuse of personal data on social networks, the rights to respect for the honor, dignity of the individual, the business reputation of individuals and legal entities are also violated. Among all the other possible violations in social networks, this one is at the intersection of violations of the ethics of Internet communication, moral norms and legal norms. Therefore, addressing the issue of protection of individuals in social networks requires not only proper legislation, but should also include legal awareness of users and sufficient support of the IT sphere. In our opinion, the complex of such measures ensures proper protection of users on social networks.

The protection of non-property rights in social media is possible without addressing to the court also. For example, the Facebook Community Standards provide for the possibility to appeal to the administration of this social network with a complaint about the user (his or her account), his or her publication or comment in which there are threats to public or personal safety, or threats of physical harm to a person, harassment or humiliation. Materials that may include violations of the rights of individuals and that are removed by the administration in the event of a complaint include:

1) pages that insult individuals;

2) images edited to humiliate individuals;

3) a photo or video depicting physical harassment posted to humiliate the victim;

4) publication of personal information for the purpose of blackmail or harassment;

5) constant harassment by sending unwanted messages or requests to add to friends. ${ }^{32}$

However, the Statement of Rights and Responsibilities in Facebook states that the administration is not responsible for any actions of the user, and any claims, grounds of claim, disputes with the administration of the network. All claims users should address exclusively to the federal district court of the Northern district of California or in the court of the state of California. ${ }^{33}$ This is another difficulty in defending of non-property rights in social media.

The most common attempts to violate the right to respect for the dignity of the individual in social networks is cyberbullying. The phenomenon of "harassment", insult, brutal, outrageous criticism, discrimination on the Internet through bullying, trolling, is known as cyberbullying ${ }^{34}$. According to some statistics, $73 \%$ of adult Internet users have witnessed someone being harassed online, and $40 \%$ have been victims of online harassment themselves. Of those users who personally experienced online harassment, they found that they were victims of at least one of the following online: $27 \%$ of users were called offensive names, $22 \%$ of users tried to deliberately embarrass, $8 \%$ threatened users with physical violence, $8 \%$ harassed, $7 \%$ of users were harassed for a long time and $6 \%$ of users were sexually harassed. Half of the interviewed people did not know the person who persecuted them. The study also indicates that $66 \%$ of online harassment took place on social networks and their applications. However, the statistics of interaction of victims of Internet harassment with law enforcement agencies seem alarming, as there were only $5 \%$ of them. ${ }^{35}$

Another problem of judicial protection and even self-defense on the social network through the mechanisms available there, is that the person who is guilty of spreading inaccurate information on the Internet, in particular on social networks, on websites, is difficult to identify. The domain name and website can be owned by different people, and the same website can be hosted on two different domain names. Therefore, to equate the owners of domain names and websites and to prosecute for inaccurate information posted on the Internet on the website of the domain name owner who does not control this website is unacceptable. ${ }^{36}$

The website owner is able to independently control the content on his or her site, so he or she can easily remove negative materials on the site and block users. However, today website owners have only one option to address the

\footnotetext{
${ }^{31}$ Pfo O. (2016). Protection in social networks. Current issues and achievements in the field of cybersecurity, 3, p. 200-201.

32 Facebook. (2020). Community Standards. [online]. Retrieved from: https://www.facebook.com/communitystandards/recentupdates/violence_criminal_behavior[Accessed 15 June, 2020].

${ }^{33}$ Milash V. (2016). Legal aspects of the emergence and implementation of contractual relations on the Internet. Legal regulation of relations on the Internet. Kharkiv: "Law”, p. 52-91.

${ }^{34}$ Adediran A. (2020). Cyberbullying in Nigeria: Examining the Adequacy of Legal Responses. International journal for the semiotics of law. [online]. Retrieved from: https://link.springer.com/article/10.1007\%2Fs11196-020-09697-7

${ }_{35}$ Duggan M. (2014). Online Harassment. [online]. Retrieved from: https://www.pewresearch.org/internet/2014/10/22/online-harassment/ [Accessed 15 June, 2020].

${ }^{36}$ Nekit K., Ulianova G. \& Kolodin D. (2019). Website as an object of legal protection by Ukrainian legislation. Amazonia investiga, 8 (21), p. $222-230$.
} 
issue of critically negative content, which violates, in particular, the right to respect for the honor and dignity of the individual, the business reputation of individuals and legal entities: to block the user or delete the information. Such an approach does not rule out that the offender will create a new user profile and continue to infringe on the rights of other users ${ }^{37}$. We believe that it would be more effective to not only block the user, but also to make it impossible to create another account at the same IP address. Such measures will make Internet users to treat their actions and words more thoroughly, consciously and responsibly.

Another problem related to the protection of individuals on social networks is copyright infringement and infringement of personal non-property rights due to the misuse of the image of an individual. The image of an individual is recorded (photo, film, TV, video, etc.) or reproduced (through the use of drawing, sculpting, etc.) in an objective form accessible to the visual, tactile, auditory perception, information about the appearance of an individual or about its individual elements, which contains, in particular, individual features and characteristics of the face, head and other parts of the body, human figure, movements, clothing. ${ }^{38}$

It should be noted that in modern social networks, such as Instagram, the Terms of Use stipulate that the publication and use of user content in the service or through it is not a violation or misappropriation of the rights of any third party, including, inter alia, the right to privacy, the right to publicity, copyright, trademarks and (or) other intellectual property rights. ${ }^{39}$ However, the principle of fair use of copyrighted works applies in this network. Commercial use is not considered bona fide. That is, this social network prohibits the use of images without the consent of the owner and in the case of using such an image without the consent of the owner of the photo, there are some mechanisms of internal dispute resolution. Unfortunately, there is not provided the mechanism of prevention of violation of the users' rights.

\section{Conclusions and Recommendations}

In conclusion, we can say, that currently there are two ways of protection of non-property rights in the field of information communications.

The first and classical way is judicial protection. However, here we can face some issues determined by the nature of the Internet. The obvious problem of legal regulation of Internet relations is based on such features of the Internet as its global, extraterritorial nature. Therefore, there is a lack of unity of legal regulation of Internet relations not only in legal systems but also in each state. Problems could be also caused by the fact that it is difficult to identify where exactly the offence was committed and which court the claim should be addressed. Another important issue would be the identification of the offender. To improve the situation in this area we would suggest to make it obligatory to indicate the real name of the person while registering on different sites, in particular, in social media. That would make people treat more responsible to their actions and would make easier to claim the protection of non-property rights violated on the Internet.

The second way of protection of non-property rights is more modern and convenient. It is the protection by internal means of protection of rights, suggested by different platforms. Especially popular this type of protection is in social media. It can also be a kind of online dispute resolution embedded in a platform. However, such a way protection of non-property rights has also some drawbacks. For instance, being blocked or deleted, a user may register under the other nickname and continue his or her illegal activity. To prevent that we would offer to make it impossible to create another account at the same IP address.

Considering the abovementioned, we can give the following recommendations to help people to protect their nonproperty rights on the Internet:

1) Given the specifics of legal regulation of Internet legal relations of each legal system, there should be established some common criteria for legal entities. That could help to properly prevent possible offenses committed on the Internet, as well as the effectiveness of online protection methods. In particular, such criteria relate to age restrictions, which is especially relevant in the field of protection of children from the harmful effects of the Internet, and it is necessary to establish the requirement to indicate a real name. This will make it easier to identify people who are violating the rights of others online.

\footnotetext{
${ }^{37}$ Amagyrov A. \& Tserempylova E. (2016). Some Features of the Public Protection of Personal Intangible Benefits. Pravo - Jurnal Vysshei shkoly ekonomiki, 3, p. 13-29.

${ }^{38}$ Kulinich O. (2016). The concept and features of the image of an individual as an intangible asset. University scientific notes, 58, p. 89-96.

${ }^{39}$ Instagram. (2020). Community Guidelines. [online] Retrieved from: https://help.instagram.com/477434105621119?helpref=page_content [Accessed 15 June, 2020].
} 
2) It is worth to combine the judicial way of protection of non-property rights and self-defense by means provided by the website operators. Such an approach would eliminate issues caused by the extraterritorial nature of the Internet.

3) The requirement to indicate real name while registering in social media should be implemented in the national legislation. This would ensure the possibility to find out the offender. It is also worth to implement in the legislation the requirement for website operators on collaboration with the judicial system. In particular, the website owners should make impossible to create another account at the same IP address, in case non-property rights were violated from this IP address.

\section{References}

Adediran, A. (2020). Cyberbullying in Nigeria: Examining the Adequacy of Legal Responses. International journal for the semiotics of law. https://doi.org/10.1007/s11196-020-09697-7

Amagyrov, A., \& Tserempylova, E. (2016). Some Features of the Public Protection of Personal Intangible Benefits. Pravo. Jurnal Vysshei shkoly ekonomiki, 3, 13-29. https://doi.org/10.17323/2072-8166.2016.3.13.29

Baadzhi, N. (2017). Legal nature of legal relations on the Internet. Journal of Civil law, 22, 112-116.

Bezzub, I. (2018). Fight against Internet piracy in Ukraine: expert assessment. Retrieved from: http://nbuviap.gov.ua/index.php?option=com_content\&view=article\&id=874:internetpiratstvo\&catid $=8 \&$ Itemid $=350$

Bosher, H. (2020). Key issues around copyright and social media: ownership, infringement and liability. Journal of intellectual law and practice, 14(2), 123-133. https://doi.org/10.1093/jiplp/jpaa006

Cubero, D. (2017). The freedom of information facing the Internet. Revista de derecho politico, 100, 701-737. https://doi.org/10.5944/rdp.100.2017.20715

Cyberpolice Department of the National Police of Ukraine. (2017). Cyberpolice found an ex-official who "traded" personal data of Ukrainians. Retrieved from https://cyberpolice.gov.ua/news/kiberpolicziya-vykryla-eksposadovczya-yakyj-torguvav-personalnymy-danymy-ukrayincziv-foto-video-3672/

Denley, J., \& Ariel, B. (2019). Whom Should We Target to Prevent? Analysis of Organized Crime in England using Intelligence Records. European journal of crime criminal law and criminal justice, 27(1), 13-44. https://doi.org/10.1163/15718174-02701003

Duggan, M. (2014). Online Harassment. Retrieved from https://www.pewresearch.org/internet/2014/10/22/online-harassment/

European Parliament and the Council of Europe. (1995). Directive 95/46/EC of the European Parliament and of the Council of 24 October 1995 on the protection of individuals with regard to the processing of personal data and on the free movement of such data. Retrieved from https://eur-lex.europa.eu/legalcontent/en/TXT/?uri=CELEX\%3A31995L0046

Facebook. (2020). Community Standards. Retrieved from https://www.facebook.com/communitystandards/recentupdates/violence_criminal_behavior

Fernandez, J. P. (2017). Data protection and Internet search engines: current issues and future perspectives about the right to be forgotten. Revista de derecho civil, 4(4), 181-209.

Galyantych, M. (2011). Compensation for moral and material damage. Kyiv: Jurinkom Inter.

Hetman, A., \& Efremova, K. (2016). Legal nature of Internet legal relations. Legal regulation of relations on the Internet. Kharkiv: "Law".

Instagram. (2020). Community Guidelines. $\quad$ Retrieved https://help.instagram.com/477434105621119?helpref=page_content

Korchevna, L. (1998). Compensation for non-pecuniary damage caused by violation of personal non-property rights in the civil law of Ukraine. Abstract of PhD Thesis. Kharkiv: University of Internal Affairs, $24 \mathrm{p}$.

Krasytska, L. (2015). Problems of realization and protection of personal non-property and property rights of parents and children. Abstract of PhD Thesis. Kyiv: National Academy of the Prosecutor's Office of Ukraine, $49 \mathrm{p}$.

Kulinich, O. (2012). Certain issues of case law on the legality of the distribution of photographic works depicting "public" individuals. Current issues of state and law, 68, 359-365.

Kulinich, O. (2016). The concept and features of the image of an individual as an intangible asset. University scientific notes, 58, p. 89-96. 
Maleina, M. (2000). Personal non-property rights of citizens: the concept, implementation and protection. Moscow: MZ Press.

Milash, V. (2016). Legal aspects of the emergence and implementation of contractual relations on the Internet. Legal regulation of relations on the Internet. Kharkiv: "Law".

Moskalenko, M. (2016). Information protection in social networks. Current issues and achievements in the field of cybersecurity, 3, p. 143-144.

Nekit, K., Ulianova, G., \& Kolodin, D. (2019). Website as an object of legal protection by Ukrainian legislation. Amazonia investiga, 8(21), 222-230.

Nyamutata, C. (2019). Childhood in the digital age: a socio-cultural and legal analysis of the UK's proposed virtual legal duty of care. International journal of law and information technology, 27(4), 311-388. https://doi.org/10.1093/ijlit/eaz010

O’Regan, C. (2018). Hate Speech Online: an (Intractable) Contemporary Challenge? Current legal problems, 71(1), 403-429. https://doi.org/10.1093/clp/cuy012

Parliamentary Assembly of the Council of Europe. (1998). On the right to privacy: Resolution 1165 (1998) of the Parliamentary Assembly of the Council of Europe. Retrieved from: https://assembly.coe.int/nw/xml/XRef/Xref-XML2HTML-en.asp?fileid=16641\&lang\%20=en

Pelekh, M., \& Shopinski, T. (2014). Consumer protection in the field of e-commerce. Bulletin of the Ministry of Justice of Ukraine, 9, 123-128.

Perot, E., \& Mostert, F. (2020). Fake it till you make it: an examination of the US and English approaches to persona protection as applied to deepfakes on social media. Journal of intellectual law and practice, 15(1), 32-39. https://doi.org/10.1093/jiplp/jpz164

Pfo, O. (2016). Protection in social networks. Current issues and achievements in the field of cybersecurity, 3 , p. 200-201.

Radkevitch, O. (2011). Features of violation of non-property rights of the person on the Internet. Legal, normative and metrological support of the information protection system in Ukraine, 1(22), 25-29.

Suhorolskiy, P. (2016). The right to be forgotten in the legal system of the European Union: realities, problems and prospects. The science of international law at the turn of the century. Tendencies of development and transformation: special edition of scientific articles. Lviv: Ivan Franko Lviv National University, p. 90-101.

The Supreme Court of Ukraine. (2009). On judicial practice in cases of protection of dignity and honor of individuals, as well as the business reputation of individuals and legal entities: The Resolution of the Plenum of the Supreme Court of Ukraine of February 27, 2009. Visnyk of the Supreme Court of Ukraine. 2009. №3. P. 7.

Tsesis, A. (2017). Terrorist Speech on Social Media. Vanderbilt Law review, 70(2), 651-708.

United Nations General Assembly. (2016). The promotion, protection and enjoyment of human rights on the Internet. Retrieved from https://www.article19.org/data/files/Internet_Statement_Adopted.pdf

Verkhovna Rada of Ukraine. (2003). Civil Code of Ukraine adopted on January 16, 2006. Vidomosti of the Verkhovna Rada of Ukraine. 2003. №3. Art. 356.

Verkhovna Rada of Ukraine. (2010). On Personal Data Protection: Law of Ukraine of June 1, 2003 No. 2297-VI. Vidomosti of the Verkhovna Rada of Ukraine. 2010. №34. Art. 481.

Vinck, P. (2019). Transitional Justice in the Age of Social Media. International journal of transitional justice, 13(1), 105-112. https://doi.org/10.1093/ijtj/ijy034

Zaharov, D. (2007). Theoretical and practical problems of protection of personal non-property rights of citizens. Abstract of PhD Thesis. Moscow: Russian Academy of Civil Service under the President of the Russian Federation, $34 \mathrm{p}$.

\section{Copyrights}

Copyright for this article is retained by the author(s), with first publication rights granted to the journal.

This is an open-access article distributed under the terms and conditions of the Creative Commons Attribution license (http://creativecommons.org/licenses/by/4.0/). 